\title{
Non-Viral Related Liver Enzymes Elevation After Kidney Transplantation
}

\author{
Behzad Einollahi ${ }^{1, *}$; Alireza Ghadian ${ }^{1}$; Ebrahim Ghamar-Chehreh ${ }^{2}$; Seyed Moayed Alavian ${ }^{2,3}$ \\ ${ }^{1}$ Nephrology and Urology Research Center, Baqiyatallah University of Medical Sciences, Tehran, IR Iran \\ ${ }^{2}$ Baqiyatallah Research Center for Gastroenterology and Liver Diseases, Baqiyatallah University of Medical Sciences, Tehran, IR Iran \\ ${ }^{3}$ Middle East Liver Diseases Center (MELD), Tehran, IR Iran \\ ${ }^{*}$ Corresponding Author: Behzad Einollahi, Nephrology and Urology Research Center, Baqiyatallah University of Medical Sciences, Tehran, IR Iran. Tel/Fax: +98-2188934125, E-mail: \\ einollahi@numonthly.com
}

Received: November 7, 2012; Revised: October 1, 2013; Accepted: October 1, 2013

Background: Liver enzymes elevations (LEE) can be observed after kidney transplantation due to multifactorial causes.

Objectives: We performed a retrospective study on 1589 kidney transplants, 971 male and 618 female, who were hepatitis B surface antigen (HBsAg) and hepatitis C virus-antibody (HCV Ab) negative, and had no other liver diseases, to detect the prevalence of LEE and its risk factors in these patients between May 2008 and May 2010.

Patients and methods: Liver enzymes and other biochemical parameters were measured in all recipients. Patients were divided into three groups, according to laboratory test time since transplantation: Group I, less than 3 months, Group II, 4 - 12 months after transplantation, and Group III, more than one year post-transplantation.

Results: The highest LEE was more frequent in older patients $(\mathrm{P}<0.001)$ and male individuals $(\mathrm{P}<0.001)$. Aspartate aminotransferase (AST) and alanine aminotransferase (ALT) levels were higher in patients who received kidneys from deceased donors (10.4\% and $23.8 \%$, respectively) as compared to living donor transplants (5.6\% and 14.8\%, respectively) $(\mathrm{P}<0.001)$. The elevation of ALT was the liver enzyme abnormality after kidney transplantation with the highest prevalence (34.3\%). The levels of ALT and AST were significantly elevated within the first 3 months after transplantation, followed by the 4-12 months period $(\mathrm{P}<0.001)$. There was a reverse correlation between liver enzyme levels and renal allograft function in both univariate and linear regression analyses. This correlation increased over time. There was also a significant relation between cyclosporine blood levels and liver enzyme values in the univariate analysis. However, this relationship was attenuated over time. Elevated liver enzymes also correlated with anemia.

Conclusions: The LEE is a common finding among kidney transplant recipients. Serial monitoring of aminotransferases, particularly ALT, should be performed in all patients after kidney transplantation.

Keywords:Kidney; Transplantation; Cyclosporine; Aspartate aminotransferase; Alanine aminotransferase

\section{Background}

Chronic liver disease, usually caused by hepatitis B virus (HBV) and hepatitis C virus (HCV), is an important threatening complication after kidney transplantation $(1,2)$. The HCV infection is the most frequent reason of post-transplant hepatitis (3). Other viral infections, such as herpes simplex and cytomegalovirus (CMV), and immunosuppressive agents used in the kidney transplant patients, should be considered in the differential diagnosis of post-transplant hepatic dysfunction. The decrease of prevalence and incidence of HBV and HCV infections in hemodialysis and renal transplanted patients during recent years sensitize the physicians in nephrology departments to investigate for other causes of liver diseases in their patients $(1,4-7)$.

Liver enzymes elevations (LEE), including aspartate aminotransferase (AST), alanine aminotransferase (ALT), and alkaline phosphatase (ALP), are indicators of hepatocellular injury (8). Patients with increased levels of serum aminotransferases and/or gamma-glutamyl transpeptidase, should be questioned about ingestion of alcohol and hepatotoxic drugs (9). Thus, serum aminotransferase levels should be monitored in kidney transplant recipients who used potential hepatotoxic agents such as immunosuppressive drugs, statins, allopurinol, etc. There are, however, surprisingly few studies to determine the prevalence of LEE after kidney transplantation.

\section{Objectives}

This retrospective study was performed a on a reasonable number of kidney transplants to detect the prevalence of LEE and its risk factors in these patients, between May 2008 and May 2010. 


\section{Patients and Methods}

\subsection{Study Population}

We enrolled 1589 renal transplant recipients (RTRs) who were negative for hepatitis B surface antigen (HBsAg) and hepatitis $C$ virus-antibody (HCV Ab), and had no other liver diseases. Blood samples were taken from all cases (7632 samples) for the measurements of routine parameters such as liver enzymes, serum creatinine ( $\mathrm{SCr}$ ), cyclosporine (CsA) through level(CO) and 2-hour post-dose level of CsA (C2).

Patients were divided into three groups, according to laboratory test time since transplantation: Group I, less than 3 months, Group II, 4-12 months after transplantation, and Group III, more than 1 year post-transplantation.

\subsection{Data Collection}

Demographic variables and other biochemical measurements were gender of recipient and donor, age of recipient and donor, donor sources (living and deceased), blood urea, lipid profiles, fasting blood sugar (FBS), uric acid and hemoglobin ( $\mathrm{Hb})$. All recipients were followed for at least 6 months. The study was approved by the local research center ethics committee.

\subsection{Protocol of Treatment and Follow Up}

Immunosuppression maintenance in all recipients was primarily based on cyclosporine (CsA). The majority of patients also received mycophenolate mofetil/azathioprine and prednisolone. Induction therapy with anti-thymocyte globulin was routinely administered in highly sensitized cases, such as patients with high panel reactive antibody and second or third transplantation.

All patients were clinically examined and a blood sample was taken for routine laboratory test at a weekly interval until 1 month, then at two weeks period up to 3 months, followed by monthly test for 1 year and every $1-2$ months subsequently.

\subsection{Definitions}

We considered the upper limit of normal for aminotransferases (ALT and AST) at $40 \mathrm{IU} / \mathrm{L}$ and ALP to $316 \mathrm{IU} / \mathrm{L}$. Patients with renal allograft dysfunction $(\mathrm{SCr}>2 \mathrm{mg} / \mathrm{dl})$ were considered to have high ALT levels if the ALT level was $>27 \mathrm{IU} / \mathrm{l}$. It has been shown that $27 \mathrm{IU} / \mathrm{l}$ is the upper limit of ALT for dialysis patients without liver disease (10).

\subsection{Statistical Analysis}

Data were analyzed using SPSS for Windows version 17.0 (SPSS Inc., Chicago, Illinois, The USA) and the quantitative results were presented as mean $\pm S D$, while qualitative variables were expressed by number and percentage. The Kolmogorov-Smirnov test (K-S test) showed that AST and ALT levels were not distributed normally. Consequently, Spearman's correlation analysis was used to assess the correlations between liver enzymes levels with numeric variables. Chi square test was used to compare qualitative data. Comparisons of variables, such as AST, ALT and ALP, between male and female recipients, were performed using the Mann-Whitney U-test. Multiple logistic regression was also performed for abnormal ALT, considered as a categorical factor. A result was considered statistically significant when $\mathrm{P}<0.05$.

\section{Results}

\subsection{Demographic Setting}

A total of 1589 RTRs, 971 males and 618 females, were included in this study. Table 1 shows the demographic data of patients. The majority of patients received a kidney from a living unrelated donor (Table 1). The older patients had higher liver enzymes level, as compared to younger individuals (Table 2). Liver enzymes value was higher in male compared with female individuals (Table 3). The levels of AST and ALT were higher in patients who received the kidney from deceased donors, as compared to living donor transplants (10.4\% and $23.8 \%$, in deceased renal transplantation, respectively, versus 5.6\% and 14.8\%, in living renal transplantation, respectively, $\mathrm{P}<0.001)$. Conversely, ALP level was greater in living renal transplants than in those who received the kidney from a deceased donor (17\% versus $13 \%, \mathrm{P}=0.006$ ).

\begin{tabular}{|c|c|}
\hline Variable & Amounts \\
\hline Recipients Sex, Male/Female, \% & $61 / 39$ \\
\hline Donors Sex, Male/Female, \% & $83 / 17$ \\
\hline Donor Sources, LRD ${ }^{\mathrm{a}} /$ LURD $^{\mathrm{a}}$ /Deceased, \% & $8.2 / 84.9 / 6.9$ \\
\hline Times of $T x^{a}, 1 / 2 / 3$ & $1529 / 53 / 7$ \\
\hline $\operatorname{AST}^{\mathrm{a}}, \mathrm{IU} / \mathrm{L}, \mathrm{Mean} \pm \mathrm{SD}$ & $22.2 \pm 29.0$ \\
\hline $\operatorname{ALT}^{\mathrm{a}}, \mathrm{IU} / \mathrm{L}, \mathrm{Mean} \pm \mathrm{SD}$ & $30.4 \pm 46.3$ \\
\hline TB, Mean \pm SD & $1.1 \pm 3.2$ \\
\hline $\operatorname{ALP}^{\mathrm{a}}, \mathrm{IU} / \mathrm{L}, \operatorname{Mean} \pm \mathrm{SD}$ & $243.3 \pm 188.9$ \\
\hline Trough Level of $C s A^{a}, n g / m L$, Mean \pm SD & $155.1 \pm 98.1$ \\
\hline 2-h Dose CsA, ng/ml, Mean \pm SD & $518.7 \pm 174.3$ \\
\hline Age of Recipients, Mean \pm SD, $y$ & $38 \pm 15$ \\
\hline Age of Donors, Mean $\pm S D, y$ & $28 \pm 6$ \\
\hline $\mathrm{BUN}^{\mathrm{a}}, \mathrm{mg} / \mathrm{dL}$, Mean $\pm \mathrm{SD}$ & $52 \pm 31$ \\
\hline Serum $\mathrm{Cr}^{\mathrm{a}}, \mathrm{mg} / \mathrm{dL}$, Mean $\pm \mathrm{SD}$ & $1.6 \pm 0.9$ \\
\hline FBS $^{\mathrm{a}}, \mathrm{mg} / \mathrm{dL}$, Mean $\pm \mathrm{SD}$ & $103 \pm 46$ \\
\hline HDL $^{\mathrm{a}}$ Cholesterol, mg/dL, Mean \pm SD & $48.2 \pm 15.7$ \\
\hline LDL $^{\text {a }}$ Cholesterol, mg/dL, Mean \pm SD & $102.2 \pm 34.4$ \\
\hline Uric Acid, mg/dL, Mean \pm SD & $6.1 \pm 1.8$ \\
\hline$H b^{a}, g / d l, M e a n ~ \pm S D$ & $12.6 \pm 2.2$ \\
\hline \multicolumn{2}{|c|}{$\begin{array}{l}\text { a Abbreviations: ALP, alkaline phosphatase; ALT, alanine aminotransferase; } \\
\text { AST, aspartate transaminase; BUN, blood urea nitrogen; Cr, creatinine; CsA, } \\
\text { cyclosporine; FBS, fasting blood sugar; Hb, hemoglobin; HDL, high density } \\
\text { lipoprotein; LDL, low density lipoprotein; LRD, living related donor; LURD, } \\
\text { living unrelated donor; TB, total bilirubin; Tx, transplantation. }\end{array}$} \\
\hline
\end{tabular}




\subsection{Prevalence}

Table 4 demonstrates the prevalence of each liver enzyme abnormality in all patients and in the three groups. The prevalence of ALT elevation was most frequent liver enzyme abnormality after kidney transplantation (Table 4). The levels of ALT and AST were significantly elevated within the first 3 months after transplantation, followed by the $4-12$ months period $(\mathrm{P}<0.001)$. The mean of ALT was higher than the mean of AST in our patients (Table 5). However, there was no significant difference in the prevalence of elevated ALP level between the three periods after transplantation (Table 4). The mean value of ALP concentration was higher in the first 3 months after transplantation, when compared with other periods following kidney transplantation (Table 5).

Table 2. Correlation Between Liver Enzyme Levels and Other Parameters

\begin{tabular}{|c|c|c|c|c|}
\hline \multirow[t]{2}{*}{ Variables } & \multicolumn{4}{|c|}{ P value (Correlation Coefficient) } \\
\hline & AST $^{\mathrm{a}}$ & ALT $^{\mathrm{a}}$ & $\mathbf{T B}^{\mathrm{a}}$ & $\operatorname{ALP}^{a}$ \\
\hline Trough Level of CsA ${ }^{a}$ & $<0.001^{\mathrm{b}}(0.17)$ & $<0.001^{\mathrm{b}}(0.29)$ & $<0.001^{\mathrm{b}}(0.11)$ & $0.1(-0.02)$ \\
\hline 2-hours post dose CsA & $<0.001^{\mathrm{b}}(0.13)$ & $<0.001^{\mathrm{b}}(0.23)$ & $<0.001^{\mathrm{b}}(0.14)$ & $0.001^{\mathrm{b}}(-0.07)$ \\
\hline Age of Recipient & $0.06(0.02)$ & $<0.001^{\mathrm{b}}(0.07)$ & $<0.001^{\mathrm{b}}(0.09)$ & $<0.001^{\mathrm{b}}(-0.06)$ \\
\hline Age of Donor & $0.6(-0.007)$ & $0.8(-0.004)$ & $0.08(0.04)$ & $0.1(0.02)$ \\
\hline Serum Creatinine & $<0.001^{\mathrm{b}}(-0.12)$ & $<0.001^{\mathrm{b}}(-0.07)$ & $<0.001^{\mathrm{b}}(-0.02)$ & $<0.001^{\mathrm{b}}(-0.07)$ \\
\hline FBS $^{a}$ & $0.6(0.006)$ & $<0.001^{\mathrm{b}}(0.09)$ & $0.083(0.03)$ & $<0.001^{\mathrm{b}}(0.1)$ \\
\hline HDL ${ }^{a}$ Cholesterol & $0.15(0.02)$ & $0.08(0.03)$ & $<0.001^{\mathrm{b}}(0.1)$ & $<0.001^{\mathrm{b}}(-0.09)$ \\
\hline LDL ${ }^{\text {a Cholesterol }}$ & $0.4(0.01)$ & $0.06(0.03)$ & $0.1(-0.03)$ & $0.008^{b}(0.04)$ \\
\hline Uric Acid & $0.004^{b}(-0.04)$ & $<0.001^{\mathrm{b}}(-0.09)$ & $0.6(0.009)$ & $0.09(-0.02)$ \\
\hline $\mathbf{H b}^{\mathrm{a}}$ & $<0.001^{\mathrm{b}}(0.09)$ & $0.001^{b}(0.06)$ & $<0.001^{\mathrm{b}}(0.4)$ & $<0.001^{\mathrm{b}}(0.09)$ \\
\hline
\end{tabular}

Table 3. Comparisons of Liver Enzyme Levels in Both Genders

\begin{tabular}{|c|c|c|}
\hline Liver enzymes & mean $\pm S D$ & Pvalue \\
\hline $\operatorname{AST}^{\mathrm{a}}$ & & $<0.001^{b}$ \\
\hline Male & $22.9 \pm 33.9$ & \\
\hline Female & $21.0 \pm 17.8$ & \\
\hline $\mathbf{A L T}^{\mathrm{a}}$ & & $<0.001^{b}$ \\
\hline Male & $32.2 \pm 50.8$ & \\
\hline Female & $27.5 \pm 37.6$ & \\
\hline $\mathbf{T B}^{\mathrm{a}}$ & & $<0.001^{b}$ \\
\hline Male & $1.2 \pm 2.6$ & \\
\hline Female & $0.9 \pm 4.1$ & \\
\hline $\operatorname{ALP}^{\mathrm{a}}$ & & $<0.001^{b}$ \\
\hline Male & $247.1 \pm 178.1$ & \\
\hline Female & $236.6 \pm 205.6$ & \\
\hline
\end{tabular}

${ }^{\mathrm{a}}$ Abbreviations: ALP, alkaline phosphatase; ALT, alanine aminotransferase; AST, aspartate transaminase; TB, total bilirubin.

b p value $<0.05$.

Table 4. Prevalence of Liver Enzymes Elevation After Kidney Transplantation $(\mathrm{n}=1589)$

\begin{tabular}{|c|c|c|c|c|c|}
\hline Abnormal Variable & Overall & Group I ( $<3$ months) & Group II (4-12 months) & Group III (> 12 months) & Pvalue \\
\hline $\mathbf{A L T}^{\mathrm{a}}, \%$ & 34.3 & 62.3 & 53 & 29 & $<0.001^{\mathrm{b}}$ \\
\hline $\mathbf{A S T}^{\mathrm{a}}, \%$ & 6.7 & 13.4 & 10.6 & 5.6 & $<0.001^{b}$ \\
\hline $\operatorname{ALP}^{\mathrm{a}}, \%$ & 16.5 & 18.9 & 16.7 & 16.2 & 0.2 \\
\hline
\end{tabular}

\footnotetext{
a Abbreviations: ALP, alkaline phosphatase; ALT, alanine aminotransferase; AST, aspartate transaminase.
}

b p value $<0.05$ 
Einollahi B et al.

\begin{tabular}{llllll}
\hline \multicolumn{1}{l}{ Table 5. Mean Value of Liver Enzymes After Kidney Transplantation } & & & \\
\hline Variable & Overall & Group I & Group II & Group III & P value \\
\hline ALT $^{\text {a }}$, IU/L, Mean \pm SD & $30.4 \pm 46.3$ & $52.6 \pm 58.0$ & $35.3 \pm 27.5$ & $27.1 \pm 45.1$ & $<0.001^{\text {b }}$ \\
AST $^{\text {a }}$, IU/L, Mean \pm SD & $22.2 \pm 29.0$ & $23.7 \pm 10.8$ & $22.5 \pm 8.1$ & $17.7 \pm 8.4$ & $<0.001^{\text {b }}$ \\
ALP $^{\text {a }}$, IU/L, Mean \pm SD & $243.2 \pm 188.9$ & $325.9 \pm 295.3$ & $189.2 \pm 92.8$ & $214.2 \pm 100.3$ & $<0.001^{\text {b }}$ \\
\hline
\end{tabular}

a Abbreviations: ALP, Alkaline phosphatase; ALT, Alanine aminotransferase; AST, Aspartate transaminase.

b Pvalue $<0.05$.

\subsection{Correlation of Liver Enzymes Test and Other Biochemical Parameters}

\subsubsection{Univariate Analysis}

Table 2 shows the correlation of liver enzyme levels with other parameters. There was a reverse correlation between liver enzyme levels and renal allograft function. It means that lower liver enzyme values were seen in patients with renal impairment $(1.5 \pm 0.9 \mathrm{mg} / \mathrm{dL}$ vs. $1.6 \pm 0.9$ $\mathrm{mg} / \mathrm{dL}$ for AST, $\mathrm{P}=0.009$, and $1.5 \pm 0.8 \mathrm{mg} / \mathrm{dL}$ vs. $1.6 \pm 0.9$ $\mathrm{mg} / \mathrm{dL}$ for ALT, $\mathrm{P}=0.01)$. There was a significant relation between CsA blood levels and liver enzyme values. However, ALP level only correlated with C2 blood level (Table 2).

Elevated liver enzymes were correlated with anemia (Table 2). The concentrations of ALT and ALP were also correlated with FBS (Table 2). Nonetheless, ALP had a weak but significant correlation with the lipid profile (Table 2).

\subsubsection{Multivariate Regression Analysis}

In recipients with serum $\mathrm{SCr}>2 \mathrm{mg} / \mathrm{dL}$, we considered an ALT level > 27 IU/L as abnormal. Consequently, at multivariate logistic regression, renal impairment was an independent risk factor for abnormal ALT in patients with $\mathrm{SCr}>2 \mathrm{mg} / \mathrm{dL}(\operatorname{Exp}(\mathrm{B})=0.48,95 \% \mathrm{CI}$ : 0.32-0.73, $\mathrm{P}=0.001)$.

\section{Discussion}

Elevation of hepatic aminotransferases, ALT and AST, is suggestive of hepatocellular injury. Despite the importance and high prevalence of LEE after kidney transplantation, there are surprisingly few studies on the evaluation of liver enzyme levels among kidney transplant patients and risk factors of their abnormalities after kidney transplantation. In addition, to our knowledge, recent published data in literature on prevalence of liver enzymes abnormalities after kidney transplantation are scarce. The current study shows that, in a quite large sample of kidney transplant patients, liver enzymes are significantly higher in these patients, accounting around 34\% for ALT. Liver dysfunction is reported in 7-67\% of kidney transplant patients in various studies (11-14). It seems that the cause of this disparity of liver dysfunction frequency is partly due to the diagnostic criteria used, which are different. In patients with $\mathrm{SCr}<2 \mathrm{mg} / \mathrm{dL}$, we consider AST and ALT $>40 \mathrm{IU} / \mathrm{L}$ as abnormal. However, in recipients with $\mathrm{SCr}>2 \mathrm{mg} / \mathrm{dL}$, an ALT $>27 \mathrm{IU} / \mathrm{L}$ was considered as abnormal. In our study, ALT was the liver enzyme with the highest prevalence of abnormalities among kidney transplant recipients (34.3\%), especially within the first 3 months after transplantation, which is comparable with results from a previous study on 189 kidney transplants, that showed liver enzyme abnormalities in $41 \%$ of all patients (8). It is important to note that transient elevation of serum aminotransferases within the first 3 months after transplantation was commonly seen in $22 \%$ of all recipients.

Chronic liver disease, which is a frequent complication after renal transplantation, represents the fourth highest cause of death in most series (15). Patients with chronically abnormal liver function studies, with or without hepatitis B surface antigenemia, may experience prolonged allograft function, but also have a high rate of mortality from non-hepatic infection $(16,17)$. Malekzadeh et al. reported that 9 of $63(14.2 \%)$ children with history of renal transplantation had liver dysfunction (18). Malekzadeh et al. reported that only one of their patients with liver dysfunction had liver function disorder in the first month of the post-transplantation period and other showed liver enzymes abnormality after the third post-transplant month. They noticed that ALT level was higher than AST and only one case had ALP elevation. The etiology of liver dysfunction was considered azathioprine toxicity in eight patients and (CMV) in only one (18). In our study, the majority of patients had hypertransaminasemia in the first 3 months after transplant, unlike the findings of Malekzadeh et al. However, in accordance to their study, we mentioned that ALT serum levels were higher than AST serum levels (Table 3 ).

The source of allograft is important in estimating the incidence of liver enzymes elevation. In deceased transplants, this incidence is higher than in living donors (1820). Similar to these studies, we found that liver enzymes abnormalities were higher and more prevalent in deceased renal transplantations compared to living donors ones.

Lorber et al. in 1987, mentioned that $49 \%$ of their renal allograft patients had post-transplant hepatotoxicity with CsA, including hyperbilirubinemia (48\% of patients), elevated AST (47\%), ALT (73\%), LDH (84\%), and ALP (59\%). Abnormal liver enzymes usually were self-limited 
in $82 \%$ of the cases and generally occurred very soon after transplantation (76\%). The serum CsA was relatively high in these patients $(225+/-17 \mathrm{ng} / \mathrm{mL})(21)$. Their findings are similar, yet much more prevalent than ours. Our patients did not receive azathioprine and we could make abstraction of its effect on liver enzymes. We also observed that elevated liver enzymes are associated with CsA blood levels, renal allograft function and lipid profile. A low grade, transient elevation of serum aminotransferases is commonly seen in patients receiving CsA. If these elevations persist or are severe, a thorough workup, including questioning about viral hepatitis and liver biopsy, is indicated.

\subsection{Limitations}

The main limitations of this study include its retrospective nature, exclusion of non-alcoholic fatty liver disease, as the most common cause of chronic liver disease worldwide, and hepatitis E virus infection, which we did not check in patients with elevated liver enzymes. In addition, liver biopsy and molecular tests were not performed in all kidney transplants with abnormal ALT. It should be noted that liver biopsy is considered as the gold standard of diagnosis of hepatic injury. However, it is invasive, expensive, and may bear potential risks. In addition, the data for the status of opportunistic infections after kidney transplant, ischemia time, ALP bone isoenzyme, medications affecting the liver enzymes such as statins, and body mass index were not available in this study and we could not estimate the impact of these factors on liver enzyme levels after kidney transplantation. The majority of patients also received mycophenolate mofetil and prednisolone. Azathioprine was only used in a small number of patients and we did not investigate the impact of azathioprine on the liver enzymes.

The abnormal liver enzymes are a common finding among kidney transplant patients. The LEE was correlated with age, gender, source of donors, renal allograft function, anemia and CsA blood levels. Serial monitoring of aminotransferases, particularly ALT, should be performed in all patients after kidney transplantation.

\section{Acknowledgements}

We would like to thanks all the staff of Transplant centers participated in this work.

\section{Authors' Contribution}

Alavian, Einollahi, Ghadian and Ghamar-Chehreh developed the original idea and the protocol. Einollahi and Ghadian collected and analyzed data, wrote the manuscript.

\section{Financial Disclosure}

The authors declare that they have no competing interests.

\section{Funding/Support}

The authors declare not financial or material support for this study.

\section{References}

1. Agarwal SK. Hepatitis B Infection during Renal Replacement Therapy. Hepat Mon. 2010;10 (4):255-7.

2. Du LY, Tang H. Treatment of HCV patients before and after renal transplantation. Hepat Mon. 2011;11(11):880-6.

3. Rostami Z, Nourbala MH, Alavian SM, Bieraghdar F, Jahani Y, Einollahi B. The impact of Hepatitis $C$ virus infection on kidney transplantation outcomes: A systematic review of 18 observational studies: The impact of HCV on renal transplantation. Hepat Mon. 2011;11(4):247-54.

4. Einollahi B. Therapy for HBV Infection in Hemodialysis Patients: Is it Possible? Hepat Mon. 2012;12(3):153-7.

5. Mahdavi-Mazdeh M. Controlling HCV Infection in Hemodialysis Units. Nephro Urol Mon. 2011;3(4):311-2.

6. Salinitri F, Hsaiky L, Pinelli N, Alavian S. Hepatitis C virus infection complicated by kidney disease and author's reply. Nephro Urol Mon. 2011;3(4):308-10.

7. Zahedi MJ, Darvish Moghaddam S, Alavian SM, Dalili M. Seroprevalence of Hepatitis Viruses B, C, D and HIV Infection Among Hemodialysis Patients in Kerman Province, South-East Iran. Hepat Mon. 2012;12(5):339-43.

8. Alavian SM Einolahi B, Sadeghi-Gahroodi M, Hosseini SM. [Liver enzymes level evaluation in renal tranplanted group]. Modares J Med Sci. 2002;5(1):87-92.

9. Gutkowski K, Chwist A, Hartleb M. Liver injury induced by highdose methylprednisolone therapy: a case report and brief review of the literature. Hepat Mon. 2011;11(8):656-61.

10. Espinosa M, Martin-Malo A, Alvarez de Lara MA, Soriano S, Aljama P. High ALT levels predict viremia in anti-HCV-positive HD patients if a modified normal range of ALT is applied. Clin Nephrol. 2000;54(2):151-6.

11. Aronoff A, Gault MH, Huang SN, Lal S, Wu KT, Moinuddin MD, et al. Hepatitis with Australia antigenemia following renal transplantation. Can Med Assoc J.1973;108(1):43-50.

12. Berne TV, Chatterjee SN, Craig JR, Payne JE. Hepatic dysfunction in recipients of renal allografts. Surg Gynecol Obstet. 1975;141(2):171-5.

13. Ireland P, Rashid A, von Lichtenberg F, Cavallo T, Merrill JP. Liver disease in kidney transplant patients receiving azathioprine. Arch Intern Med.1973;132(1):29-37.

14. Moore TC, Hume DM. The period and nature of hazard in clinical renal transplantation. II. The hazard to transplant kidney function. Ann Surg. 1969;170(1):12-24.

15. Debure A, Legendre C, Kreis H, Degott C, Carnot F, Pol S, et al Chronic hepatitis in kidney allograft recipients. The Lancet. 1990;335(8694):878-80.

16. LaQuaglia MP, Tolkoff-Rubin NE, Dienstag JL, Cosimi AB, Herrin JT, Kelly M, et al. Impact of hepatitis on renal transplantation. Transplantation. 1981;32(6):504-7.

17. London WT, Drew JS, Blumberg BS, Grossman RA, Lyons PJ. Association of graft survival with host response to hepatitis B infection in patients with kidney transplants. $N$ Engl J Med. 1977;296(5):241-4.

18. Malekzadeh MH, Grushkin CM, Wright HT, Jr, Fine RN. Hepatic dysfunction after renal transplantation in children. $J$ Pediatr. 1972;81(2):279-85.

19. Moore TC, Hume DM. The period and nature of hazard in clinical renal transplantation. 3. The hazard to transplant kidney survival. Ann Surg. 1969;170(1):25-9.

20. Reeve CE, Martin DC, Gonick HC, Kaufman JJ, Rubini ME, Mimms MM, et al. Kidney transplantation. A comparison of results using cadaver and related living donors. Am J Med.1969;47(3):410-20.

21. Lorber MI, Flechner SM, Van Buren CT, Sorensen K, Kerman RH, Kahan BD. Cyclosporine toxicity: the effect of combined therapy using cyclosporine, azathioprine, and prednisone. Am J Kidney Dis. 1987;9(6):476-84. 